LBL-31795

UC-350

\title{
FIELD PERFORMANCE OF RESIDENTIAL REFRIGERATORS: A COMPARISON WITH THE LABORATORY TEST*
}

\author{
Alan Meier and Richard Jansky \\ Lawrence Berkeley Laboratory \\ University of California \\ Berkeley, California 94720
}

May 1991

\footnotetext{
*This research was supported by the American Society of Heating Refrigerating and Air-Conditioning Engineers, RP 607. This work was also supported by the Assistant Secretary for Conservation and Renewable Energy, Office of Building Technology, Building Systems Division of the U.S. Department of Energy under Contract No. DE-AC03-76SF00098.
}

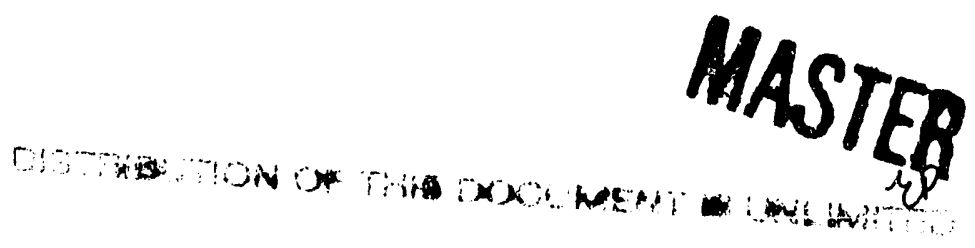


LBL-31795

UC-350

\title{
FIELD PERFORMANCE OF RESIDENTIAL REFRIGERATORS:
}

\section{A COMPARISON WITH THE LABORATORY TEST*}

\author{
Alan Meier, Ph.D. and Richard Jansky† \\ Lawrence Berkeley Laboratory \\ University of California \\ Berkeley, California 94720
}

May 1991

\begin{abstract}
The field electricity use of 209 refrigerators was compared to their labeled consumption. The mean field use of all units was $1009 \mathrm{kWh} /$ year, $882 \mathrm{kWh} /$ year for top-freezers, and 1366 $\mathrm{kWh} /$ year for side-by-sides. There was considerable scatter in the results but, in general, the label overpredicted field use. The relationship could be best described with the formula, Annual Field Use $=0.94 \times($ Annual Label Use $)-85$. For a typical unit with a labeled use of 1160 $\mathrm{kWh} /$ year, the field use was about $15 \%$ lower.

There was considerable seasonality in energy use: the peak weeks generally occurred around the beginning of August. However, there was no simple relationship between the label value and the peak-week consumption.
\end{abstract}

\section{INTRODUCTION}

Residential refrigerators consume about $7 \%$ of the nation's electricity and are the largest end use of electricity in homes. It is therefore important to understand their energy use and to be able to forecast future energy requirements. Energy use of refrigerators has attracted greater

* This research was supported by the American Society of Heating Refrigerating and AirConditioning Engineers, RP 607. This work was also supported by the Assistant Secretary for Conservation and Renewable Energy, Office of Building Technology, Building Systems Division of the U.S. Department of Energy under Contract No. DE-AC03-76SF00098. 
attention recently due to the establishment of minimum efficiency standards and various utility incentives to encourage consumers to buy more efficient units. The purpose of this project is to compare refrigerator energy use in the field and in the laboratory.

The ANSI/AHAM laboratory test procedure (Association of Home Appliance Manufacturers (AHAM), 1988) (commonly called "the DOE test") is the accepted method of measuring a refrigerator's energy consumption in the laboratory. The results of the DOE test are used to prepare the energy consumption labels now found on all refrigerators. The national minimum efficiency standards are expressed in terms of the DOE test. Utility planners use these results to forecast energy demand and to set consumer incentives. For these reasons, it is essential to ensure that the laboratory test is an accurate predictor of field energy use.

\section{THE DEPARTMENT OF ENERGY TEST}

The Department of Energy Test (ANSI/AHAM HRF-1-1988) was originally developed by refrigerator manufacturers over fifteen years ago. There have been modest modifications to accommodate innovations in refrigerator technology, but the general procedure has not been changed. The test is closed-door and does not involve food loads. The absence of dooropenings and food loading is offset by a high ambient temperature of $32^{\circ} \mathrm{C}\left(90^{\circ} \mathrm{F}\right)$. Some of the details of the test are presented in Table 1. Key features of the Japanese and ISO test procedures are also shown.

The test procedure does not simulate other real-world conditions of refrigerator operation that can influence energy use. For example, adequate ventilation for the condenser coils is also very carefully specified in the test but air movement is often very constricted in real locations. This will reduce the ability of the refrigerator to remove heat. In one case, improved ventilation cut electricity consumption by $15 \%$. (Meier, 1991) The number of times which doors are opened will also affect energy use. However, many openings are required to significantly increase energy use. Alissi et al. (Alissi et al., 1988) found that energy use will increase about $25 \%$ for a typical top-freezer refrigerator when measured from a condition of no openings to about 100 door openings per 24 hours. (Families typically open the refrigerator 50 times per day.) The Japanese refrigerator test procedure includes door openings. (Japan Standards Association, 1986) Meier (Meier, 1987) compared the energy use of refrigerators when tested by both the Japanese test procedure and the DOE test. The JIS test procedure yielded lower energy use than the DOE test because other test features offset the door-opening. Refrigerators in the field may have different freezer and fresh-food temperatures. These units may also suffer from dirty condenser coils or the sun shining on them. The impact on energy consumption of these factors has not been well studied.

The energy use of some features of modern refrigerators are also not captured by the test procedure. For example, adaptive (or demand) defrost controls effectively insure that the defrost will not switch on during the test period (since no ice build-up will be detected). The icemaker and cold-water dispenser also draw energy during standard use but are not connected during the DOE test.

Refrigerator manufacturers perform the DOE test on a random sample of their units in order to determine the energy consumption reported on the energy consumption label. The "label" consumption for a particular model is determined when a specific confidence level is achieved. The details are described in the Federal Register. (U.S. Department of Energy, 1979) Typically, five to six units are needed to achieve this level of confidence. So there is some 
uncertainty regarding the consistency of the "label" consumption and the true consumption for a specific unit.

\section{PREVIOUS COMPARISONS OF FIELD AND LABORATORY CONSUMPTION}

Several comparisons of field and laboratory energy use have been performed. Most were limited to a few refrigerators, a single model, a single geographical region, or a short-term monitoring period. Furthermore, the objectives of these studies differed greatly, from field-testing new refrigerator technologies to validation of short-term monitoring procedures. Typical studies include those by Sherman et al, (Sherman, 1987) Arthur D. Little (Arthur D. Little, Inc., 1982) and Topping. (Topping, 1982)

These studies found considerable variation in energy use depending on location and conditions investigated. For example, Arthur D. Little found that Florida refrigerators used at least $20 \%$ more than the labeled (that is, the DOE test) use. Topping encountered such great variation among identical units that no comparison with the label was appropriate.

Recently, Meier and Heinemeier, (Meier \& Heinemeier, 1988) compiled field data from other studies. By matching model numbers of the monitored refrigerators with those listed in the Association of Home Appliance Manufacturers directories (Association of Home Appliance Manufacturers (AHAM), 1991) it was possible to compare field and labeled use. Altogether, 259 refrigerators were compiled. In that study, and a slightly expanded study, (Heinemeier \& Meier, 1988) Meier and Heinemeier found that the DOE test was quite accurate for predicting the annual average consumption of a large group of refrigerators. However, there was considerable scatter for individual units. The test value slightly underpredicted average monthly consumption.

\section{PROCEDURE}

We obtained monitored data from utilities, research institutions, and individuals. We then determined the labeled energy use of the refrigerators from annual directories by matching model numbers. The sample is thus not statistically representative nor uniform in accuracy or detail.

Some of the data were collected at irregular intervals, ranging from one day to a month. We mapped the data into standard "weeks". This involved combining some data and small extrapolations of other intervals to whole weeks. This procedure will have a negligible effect on annual consumption but can lead to distortions in individual weekly use.

To improve uniformity of data and analysis, certain data restrictions were established. The data included in the analysis must have the following characteristics.

- Every refrigerator must be listed in the AHAM directories or have DOE test data.

- Measurements must be collected at least every month.

- The refrigerator must have been monitored at least nine months.

These restrictions greatly reduced the number of qualifying refrigerators. For example, we were able to match less than half of the model numbers (provided by our data sources) with entries in the Directories. The largest problem were errors in transcribing the model numbers from the nameplates, which are often inconveniently located, dirty, and poorly printed). Many large utility monitoring studies, with excellent energy data, failed to collect model numbers. In addition, the directories were not available for three years. 
There were four major sources of data for this study. The first set of data was compiled from Heinemeier and Meier. Of the 194 refrigerators only 127 had monthly consumption data. The significance of the remaining 127 units was further limited due to several large groups (up to 20) of identical units. One of these groups of identical refrigerators had an extremely wide distribution of energy use and possible technical problems. After consulting with the researcher responsible, the data were omitted, thus reducing the data set to 112 usable units.

The second set of data was obtained from the Bonneville Power Administration's Residential Construction Demonstration Project (RCDP). This project, operated by the Washington State Energy Office in four Northwestern states, sought to demonstrate innovative energy efficient technologies. We were supplied weekly data for 181 refrigerators. Due to the restrictions described above, only 62 of these units could be used in this analysis.

The third set of data came from BPA's End-Use Load and Consumer Assessment Program (ELCAP). This monitoring program included almost one hundred refrigerator circuits (which included other miscellaneous, usually small, appliances) but only 41 refrigerators were monitored on pure circuits. Again, with the restrictions described above, only 22 units could be used. The refrigerator data were provided at daily intervals.

The fourth data source consisted of measurements of twelve Japanese refrigerators. (Short, 1990) While their DOE test consumptions were not listed in AHAM Directories, Meier's earlier study (Meier, 1987) had measured these units. All of these units were located in the Pacific Northwest. Energy use was recorded at irregular intervals. To obtain weekly consumptions, the data was normalized.

Many other sources of data were identified, inspected, and rejected for not meeting the restrictions described above. Considerably more data will be available soon. For example, at least three utility studies, metering hundreds of refrigerators, are presently underway. Table 2 indicates the extent of data shrinkage due to the restrictions described above.

\section{RESULTS}

Data on 432 refrigerators were collected; however, only 209 refrigerators met the requirements described earlier. These 209 were used in all subsequent analyses. Of the 209 refrigerators, $72 \%$ were top-freezers and $23 \%$ side-by-sides. (The remainder were bottom-freezers.) Nearly all of the refrigerators were located in northern climates, with the majority in the Pacific Northwest. The following sections describe details of the refrigerators' energy use.

\section{Mean Energy Use and Distribution}

The mean measured energy use of the 209 refrigerators was $1009 \mathrm{kWh} /$ year. The mean labeled energy use of the same refrigerators was $1160 \mathrm{kWh} /$ year. Figure 1 shows the distribution of measured and labeled energy use. One unit used as little as $260 \mathrm{kWh} /$ year while another used as much as $2377 \mathrm{kWh} /$ year. The shapes of the distributions are different. The shape of the labeled distribution is relatively symmetric while the monitored distribution is shifted towards the lower consumptions with a long tail on the high side. The top-freezers consumed an average of $882 \mathrm{kWh} /$ year in the field, while the side-by-sides consumed considerably more, 1366 $\mathrm{kWh} /$ year. 


\section{Label vs. Field Consumption}

The labeled energy use of the 209 units was obtained from the AHAM directories, other reports, and personal communications from the manufacturers. Figure 2 shows the comparison of the labeled and field annual electricity use. A line of equality is included; if a point lies directly on the equality line, then the labeled and field consumption are identical.

There is considerable scatter. but increasing field energy use clearly correlates with higher

label energy use. A linear regression yielded the following relationship between label and field energy use:

$$
\text { Annual Field Use }=0.94 \times(\text { Annual Label Use })-85
$$

The linear regression is shown as a dark line in Figure 2. The regression suggests that the label overpredicts field consumption for this group of refrigerators. The field use of an average refrigerator in this compilation (with a labeled consumption of $1160 \mathrm{kWh} /$ year) is about $15 \%$ below the label. The Coefficient of Determination (or $\mathrm{R}^{2}$, indicating the fraction of field use explained by the regression) is 0.64 . This suggests that $36 \%$ of the field energy use is determined by factors other than the label energy use. These might include door openings, ambient temperature, and other factors unique to each unit.

A similar comparison was made for top-freezers and side-by-sides alone. Figures 3 and 4 show the results, along with the regressions. The regression for 150 top-freezers is described by:

$$
\text { Annual Field Use }=0.77 \times(\text { Annual Label Use })+82
$$

and for the 49 side-by-sides by:

$$
\text { Annual Field Use }=0.98 \times(\text { Annual Label Use })-99
$$

The standard deviations are 263 and $362 \mathrm{kWh} /$ year, respectively. The Coefficients of Determination are 0.46 and 0.52 , respectively.

The scatter in the data is still very large; however, the siopes of the regressions for the two designs differ. The side-by-sides, on average, correlate very closely with the label but field use is about $100 \mathrm{kWh} /$ year less than the label. In contrast, the regression for top-freezers has a slope significantly less than one (0.77). Thus top-freezers in the field energy use about $18 \%$ less than the label (for the average unit with a labeled consumption of $1045 \mathrm{kWh} / \mathrm{year}$ ). The results are summarized in Table 3.

\section{Seasonal Energy Use}

The electricity use of refrigerators is very sensitive to ambient temperatures. Refrigerators are generally located in conditioned spaces, so large ambient temperature variations are dampened. Nevertheless, even a kitchen experiences significant seasonal temperature fluctuation. Other factors, such as increased ice making and beverage cooling, will also raise summer energy use.

There was considerable seasonality in monitored energy use: the summer use clearly exceeded the winter use. The peak weeks occur around the beginning of August but there remains some uncertainty. It is not surprising that no single week emerges as the clear peak because the data come from many sources, years, and locations. In addition, the procedure to transform the original data into uniform weeks introduces further uncertainty. 
The relationship between the label and peak week was also investigated. The comparison actually involved the label divided by 52 , so that both values were in weeks. Many refrigerators exhibited a wide range in week-to-week consumption (as shown in Figure 5). A few of the peaks and minimums may be spurious, and simply reflect interpolation errors. Nevertheless, the mean of the peak consumptions was $40 \%$ greater than the mean of the labeled values (which was $19 \mathrm{kWh} /$ week). Over $10 \%$ of the refrigerators experienced a weekly peak consumption over twice the labeled value. Six refrigerators reported at least one week of zero energy use. It could not be determined why no consumption was recorded, even though the unit was clearly in use for the year. Unfortunately, there was no simple relationship between the label value and the peakweek consumption. The regression results (of label/52 versus peak week) are shown in Table 3 .

\section{Effect of Age and Volume on Energy Use}

In principle it is possible to identify the construction year of any unit from its model number and serial number. Unfortunately each manufacturer uses a different system, and often manufacturers the same unit for several years. Without precise decoding information of the serial number from the manufacturers, it was impossible to construct a meaningful relationship between age and energy use. Refrigerators in this compilation, however, are probably newer than the stock average because the monitoring projects focused on new homes.

We also tested the relationship between refrigerator volume and energy use. Total refrigerator volume proved to be a poorer predictor of field energy use than the label. However, this relationship allows one to compare field energy use to present and future energy efficiency standards. Figure 6 shows the performance of top-freezer units compared to national energy efficiency standards. (Nominal volumes were converted to adjusted volumes by multiplying by 1.14.) Some units already achieved the 1993 standard levels in the field, but the majority are considerably above.

\section{CONCLUSIONS}

We compiled diverse field data and matched them to laboratory test data for 209 refrigerators. The average monitored energy use of refrigerators in the compilation was $1009 \mathrm{kWh} / \mathrm{year}$. This value is lower than that assumed in some of the major forecasting models. For example, the unit energy consumption in the forecasting model LBL-REM is $1226 \mathrm{kWh}$ /year. (Atkinson, 1991) Yet these values may be consistent because our compilation contains refrigerators located mostly in northern climates, where kitchens are generally cooler. In addition, the refrigerators are probably newer than average because many of the monitoring studies concentrated on new homes.

Among the refrigerators examined, the DOE test (as reflected in the labeled consumption) was a moderately good predictor of field use. The regression indicated that field use was about $140 \mathrm{kWh} /$ year less than the label for a wide range of consumption. For the average unit, with a labeled energy use of $1160 \mathrm{kWh} / \mathrm{year}$, the field use is about $15 \%$ less. To be sure, there is considerable variation in individual use (reflecting differences in location, usage, etc.) but the overall trend is clear.

Different relationships emerge when the compilation is separated into top-freezer and sideby-side designs. The side-by-sides used about $100 \mathrm{kWh} / y$ ear less than the label over a wide range. In contrast, the performance of the top-freezers are close to the label at the lower range $(750 \mathrm{kWh} /$ year) but diverge at higher consumptions. 
Refrigerator energy use is often considered relatively constant. In fact, our compilation indicates that there is strong seasonality of consumption. The label energy use (divided by 52) is a poor predictor of peak-week consumption because peak use can be much higher and is highly variable.

The procedure used to obtain data for this project is inefficient and susceptible to errors. The quality and quantity of data from this kind of project could be greatly enhanced with relatively modest improvements in coordination of data collection and compilation. Nevertheless, these errors can be minimized through careful filtering and inspection. The procedure, while tedious, is certainly less expensive than initiating a monitoring project de novo.

\section{ACKNOWLEDGEMENT}

This research was supported by the American Society of Heating Refrigerating and AirConditioning Engineers, RP 607. This work was also supported by the Assistant Secretary for Conservation and Renewable Energy, Office of Building Technology, Building Systems Division of the U.S. Department of Energy under Contract No. DE-AC03-76SF00098. We gratefully acknowledge the assistance of the many institutions that provided us data for this project. In addition, we thank Bruce Nordman for his assistance in the data analysis.

\section{REFERENCES}

Alissi, M., Ramadhyani, S. \& Schoenhals, R. (1988). ASHRAE Transactions 94, 1713-1735.

Arthur D. Little, Inc. (1982). ADL 86737, Cambridge, MA. Final Report to Florida Public Service Commission.

Association of Home Appliance Manufacturers (AHAM). (1975-1991). Directory of Certified Refrigerators and Freezers, Chicago.

Association of Home Appliance Manufacturers (AHAM). (1988). ANSI/AHAM HRF-1-1988, Chicago.

Atkinson, C. (March 9, 1991). Lawrence Berkeley Laboratory. Personal communication.

Heinemeier, K. \& Meier, A. K. (1988). Proceedings of the ACEEE 1988 Summer Study on Energy Efficiency in Buildings, American Council for an Energy Efficient Economy, Asilomar, CA. LBL-25612.

Japan Standards Association. (1986). JIS C 9607.

Meier, A. K. (1987). ASHRAE Transactions 93.

Meier, A. K. \& Heinemeier, K. (1988). ASHRAE Transactions 94, Part 2. LBL-25613.

Meier, A. (March 1991). Home Energy 8, 7-8.

Sherman, M. (1987). LBL-23455, Lawrence Berkeley Laboratory, Berkeley.

Short, J. (October 1990). Lambert Engineering Co.. Personal communication.

Topping, R. (1982). ORNL Sub 77-7255-3, Oak Ridge National Laboratory, Oak Ridge.

U.S. Department of Energy. (April 13, 1979). Federal Register 44, 22410-22418. 
TABLE 1

Key features of the DOE, Japanese and ISO test procedures

\begin{tabular}{|c|c|c|c|}
\hline Parameter & $\begin{array}{c}\text { Dept. of Energy } \\
\text { ANSI HRF-1-1988 } \\
\end{array}$ & $\begin{array}{c}\text { Japan Industrial } \\
\text { Standard } \\
\text { JIS C-9607-1986 } \\
\end{array}$ & $\begin{array}{l}\text { International } \\
\text { Standards Org. } \\
\text { ISO/DIS } 8187\end{array}$ \\
\hline $\begin{array}{ll}\text { Test } & \text { Chamber } \\
\text { Ambient } & \text { Tempera- } \\
\text { ture } & \end{array}$ & $90 \pm 1^{\circ} \mathrm{F}$ & $\begin{array}{l}59 \pm 1.8^{\circ} \mathrm{F} \text { and } \\
86 \pm 1.8^{\circ} \mathrm{F}\end{array}$ & $\begin{array}{l}77^{\circ} \mathrm{F} \pm 0.9^{\circ} \mathrm{F} \\
\text { Tropical } 89.6^{\circ} \mathrm{F}\end{array}$ \\
\hline $\begin{array}{l}\text { Weighting of } \\
\text { Annual Results by } \\
\text { Chamber Ambient } \\
\text { Temperature }\end{array}$ & 365 Days@90F & $\begin{array}{l}265 \text { Days@ } 59^{\circ} \mathrm{F} \\
100 \text { Days@ } 86^{\circ} \mathrm{F}\end{array}$ & 365 days @ 77 F \\
\hline $\begin{array}{lr}\text { Test } & \text { Chamber } \\
\text { Ambient } & \text { Relative } \\
\text { Humidity } & \end{array}$ & No Specification & $75 \% \pm 5 \%$ & $45-75 \%$ \\
\hline Door Openings & None & $\begin{array}{l}\text { Fresh Food - every } 12 \mathrm{~min} . \\
\text { Freezer - every } 40 \mathrm{~min} \text {. } \\
\text { (during first } 10 \text { hours of test. } \\
\text { Duration of opening } 15 \\
\text { seconds) }\end{array}$ & None \\
\hline $\begin{array}{l}\text { Fresh Food and } \\
\text { Freezer Compart- } \\
\text { ment Loads }\end{array}$ & $\begin{array}{l}\text { None (except for low-temp. } \\
\text { compartment of basic refri- } \\
\text { gerator) }\end{array}$ & $\begin{array}{l}\text { None for energy consump- } \\
\text { tion test }\end{array}$ & $\begin{array}{l}3.6 \mathrm{lbs} \text {. load in freezer with } \\
\text { thermal characteristics of } \\
\text { lean beef }\end{array}$ \\
\hline $\begin{array}{l}\text { Freezer Standard } \\
\text { Temperatures }\end{array}$ & $\begin{array}{l}5^{\circ} \mathrm{F} \text { (Freczer of Ref./Fre.) } \\
15^{\circ} \mathrm{F} \text { (Freezer of Basic Ref.) }\end{array}$ & $\begin{array}{l}-0.4^{\circ} \mathrm{F} \text { (Three-star rated } \\
\text { unit) } \\
10.4^{\circ} \mathrm{F} \text { (Two-star rated unit) } \\
21.2^{\circ} \mathrm{F} \text { (One-star rated unit) }\end{array}$ & $\begin{array}{l}0^{\circ} \mathrm{F} \quad \text { Freezer (Three-star } \\
\text { unit) } \\
41^{\circ} \mathrm{F} \text { Fresh Food }\end{array}$ \\
\hline $\begin{array}{l}\text { Fresh Food Standard } \\
\text { Temperature } \begin{array}{l}\text { Test } \\
\text { Period }\end{array}\end{array}$ & $\begin{array}{l}\text { Defrost-to-Defrost for auto } \\
\text { defrost; at least } 3 \text { hours with } \\
\text { at least } 2 \text { compressor cycles } \\
\text { for manual defrost }\end{array}$ & $\begin{array}{l}24 \text { hour ( } 48 \text { hours or longer } \\
\text { if defrost cycle every } 2 \text { days } \\
\text { or longer) }\end{array}$ & $\begin{array}{l}\text { At least } 24 \text { hours and whole } \\
\text { number of defrost cycles. }\end{array}$ \\
\hline $\begin{array}{l}\text { Number of thermo- } \\
\text { couples for each } \\
\text { compartment }\end{array}$ & $\begin{array}{l}\text { Freezer - } 3 \text { (except basic) } \\
\text { Fresh Food - } 3\end{array}$ & $\begin{array}{l}\text { Freezer - } 3 \\
\text { Fresh Food - } 1\end{array}$ & $\begin{array}{l}\text { Freezer - } 3 \\
\text { Fresh Food - } 3\end{array}$ \\
\hline $\begin{array}{l}\text { Anti-Condensate } \\
\text { Heater Switch Set- } \\
\text { ting }\end{array}$ & $\begin{array}{l}\text { Test both "on" and "off", } \\
\text { average results }\end{array}$ & $\begin{array}{l}\text { On for both conditions (for } \\
\text { units tested) }\end{array}$ & $\begin{array}{l}\text { On if needed to pass con- } \\
\text { densation test. }\end{array}$ \\
\hline $\begin{array}{l}\text { Method of Deter- } \\
\text { mining Consump- } \\
\text { tion at a Standard } \\
\text { Temperature }\end{array}$ & $\begin{array}{l}\text { Interpolation of two tests } \\
\text { bracketing standard tem- } \\
\text { perature conditions }\end{array}$ & $\begin{array}{l}\text { Run tests at standard tem- } \\
\text { perature, within } \pm 0.9^{\circ} \mathrm{F} \\
\text { tolerance }\end{array}$ & $\begin{array}{l}\text { With all interior tempera- } \\
\text { tures below limits or inter- } \\
\text { polation of two tests. }\end{array}$ \\
\hline
\end{tabular}


TABLE 2

Extent of data shrinkage due to quality restrictions.

\begin{tabular}{|l|cc|}
\hline Owner & Provided Units & Used Units \\
\hline RCDP & 181 & 62 \\
ACEEE & 194 & 112 \\
ELCAP & 41 & 22 \\
Lambert Eng. & 12 & 12 \\
Consumer & 4 & 1 \\
\hline TOTAL & $\mathbf{4 3 2}$ & $\mathbf{2 0 9}$ \\
\hline
\end{tabular}

TABLE 3

Summary of regression results.

\begin{tabular}{|c|c|c|c|c|c|}
\hline Group & $\begin{array}{l}\text { No. of } \\
\text { Units }\end{array}$ & Regression Formula & $\begin{array}{c}\text { S.D. } \\
(\mathbf{k W h} / \mathbf{y r})\end{array}$ & $\mathbf{R}^{2}$ & $\begin{array}{c}\text { Mean } \\
(\mathbf{k W h} / \mathbf{y r})\end{array}$ \\
\hline All & 209 & Annual Field Use $=0.94 \times($ Annual Label Use $)-85$ & 359 & .64 & 1009 \\
\hline T-statistics & & 19.3 & & & \\
\hline Top-freezers & 150 & Annual Field Use $=0.77 \times($ Annual Label Use $)+82$ & 263 & .46 & 882 \\
\hline T-statistics & & 11.1 & & & \\
\hline Side-by-sides & 49 & Annual Field Use $=0.98 \times($ Annual Label Use $)-99$ & 362 & .52 & 1366 \\
\hline \multirow[t]{2}{*}{ T-statistics } & & 7.2 & & & \\
\hline & & & $(\mathrm{kWh} / \mathrm{wk})$ & & $(\mathrm{kWh} / \mathrm{wk})$ \\
\hline All & 209 & Peak Week Use $=1.1 \times($ Weekly Label Use $)+8$. & 17 & .14 & 31 \\
\hline T-statistics & & 5.7 & & & \\
\hline
\end{tabular}




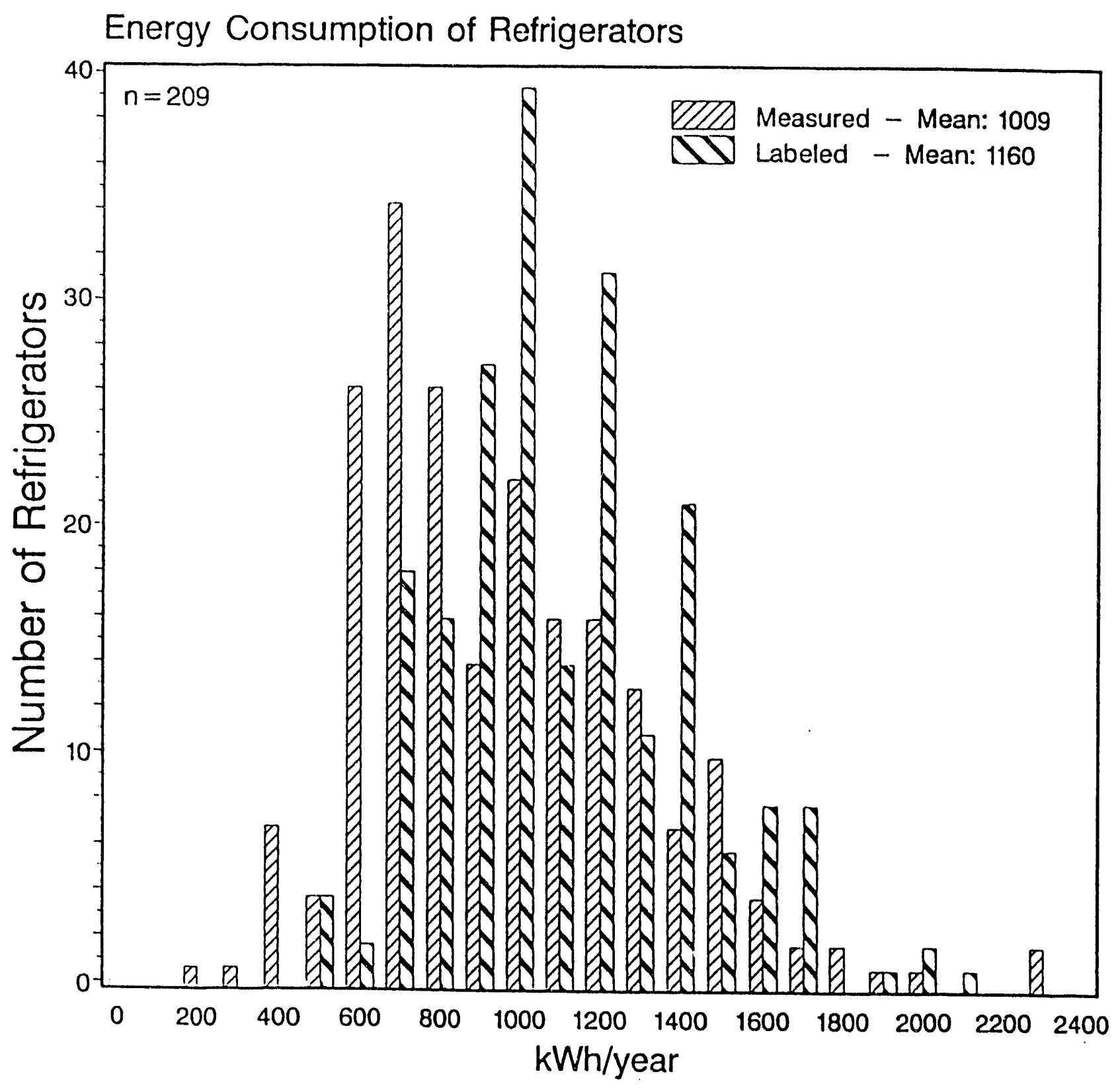

Figure 1. Distribution of measured and labeled energy use. Each bar represents all refrigerators with energy consumption in a $100 \mathrm{kWh} / \mathrm{year}$ bin. 


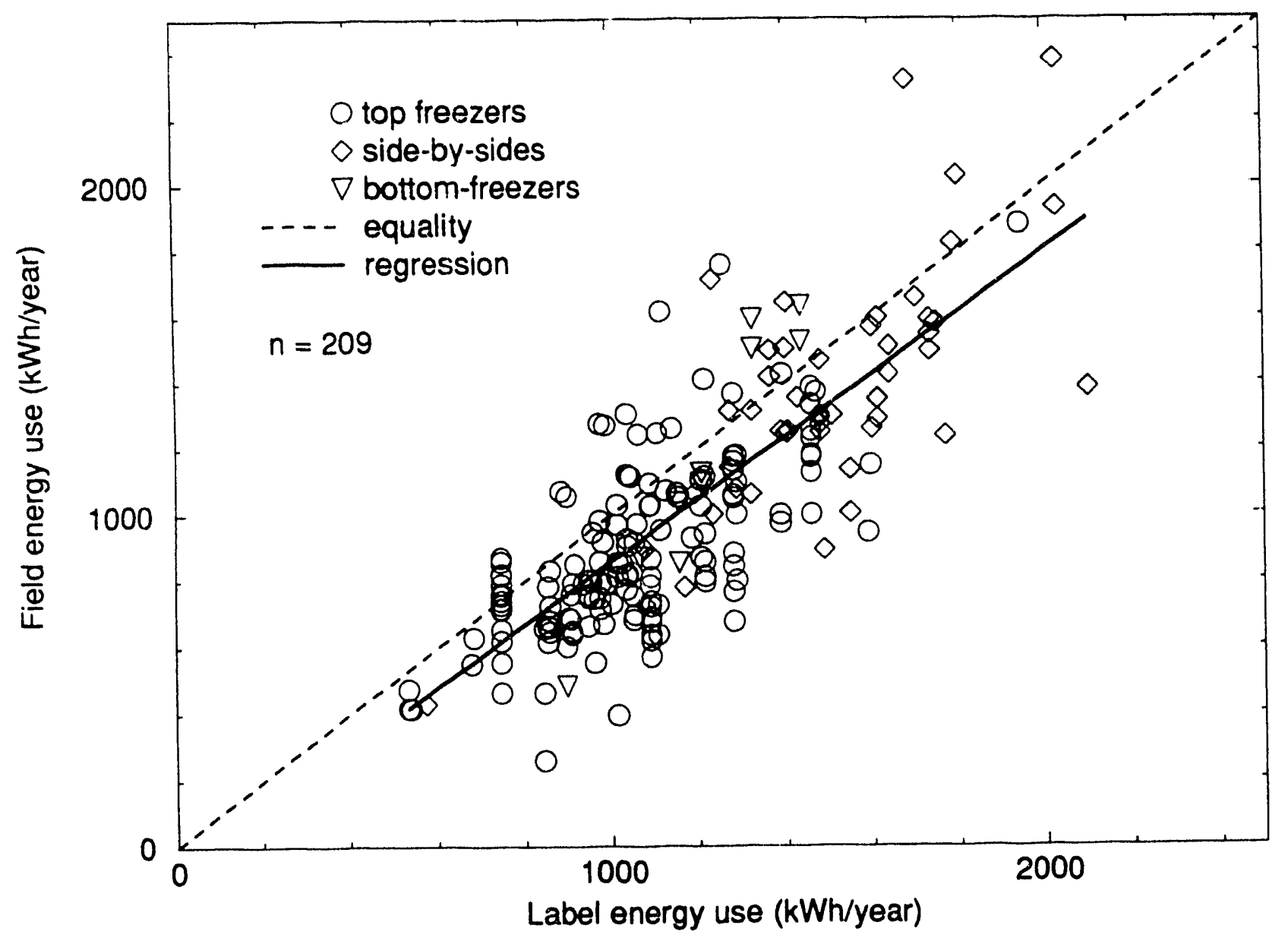

Figure 2. A comparison of the labeled and field annual electricity use. Each symbol represents one refrigerator. For reference, the dashed line indicates equal consumption in label and field. The heavy, solid line represents a regression fit. 


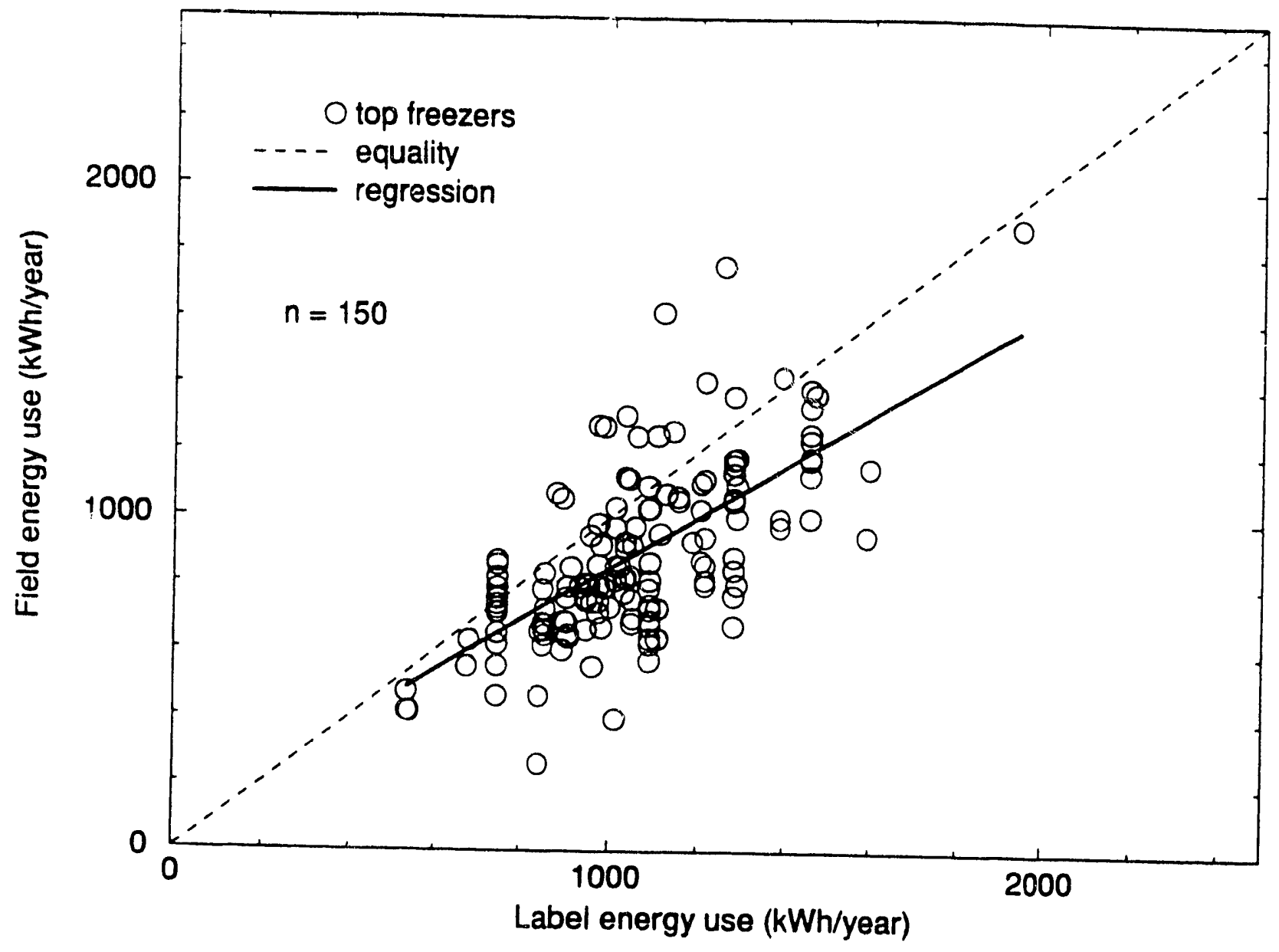

Figure 3. Field and label energy use for top-freezer refrigerators. Each diamond represents one refrigerator. For reference, the thin, solid line indicates equal consumption in label and field. The heavy, solid line represents a regression fit. 


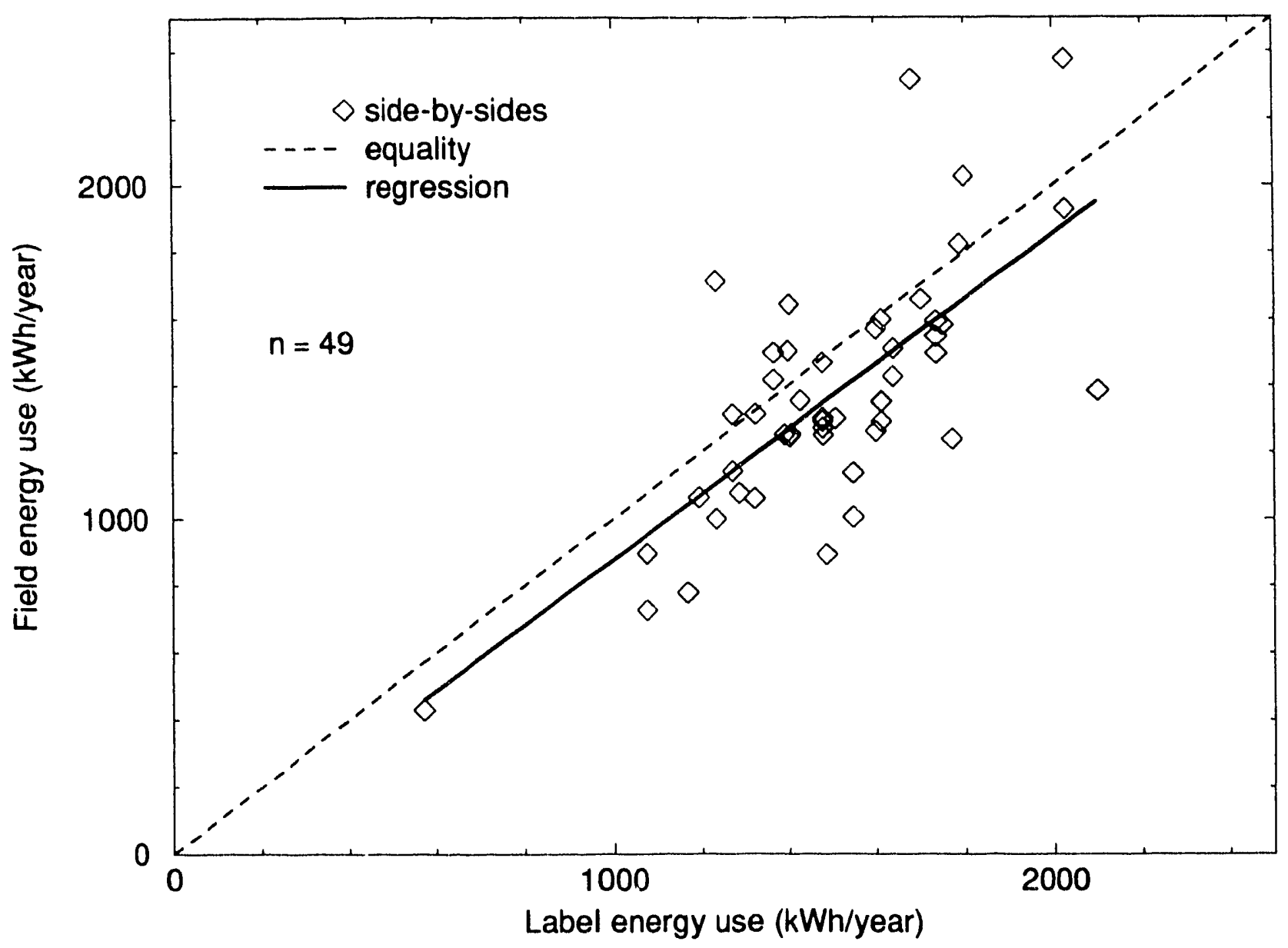

Figure 4. Field and label energy use for side-by-side refrigerators. Each diamond represents one refrigerator. For reference, the thin, solid line indicates equal consumption in label and field. The heavy, solid line represents a regression fit. 


\section{Weekly Energy Consumption Distribution: Monitored vs. Labeled}

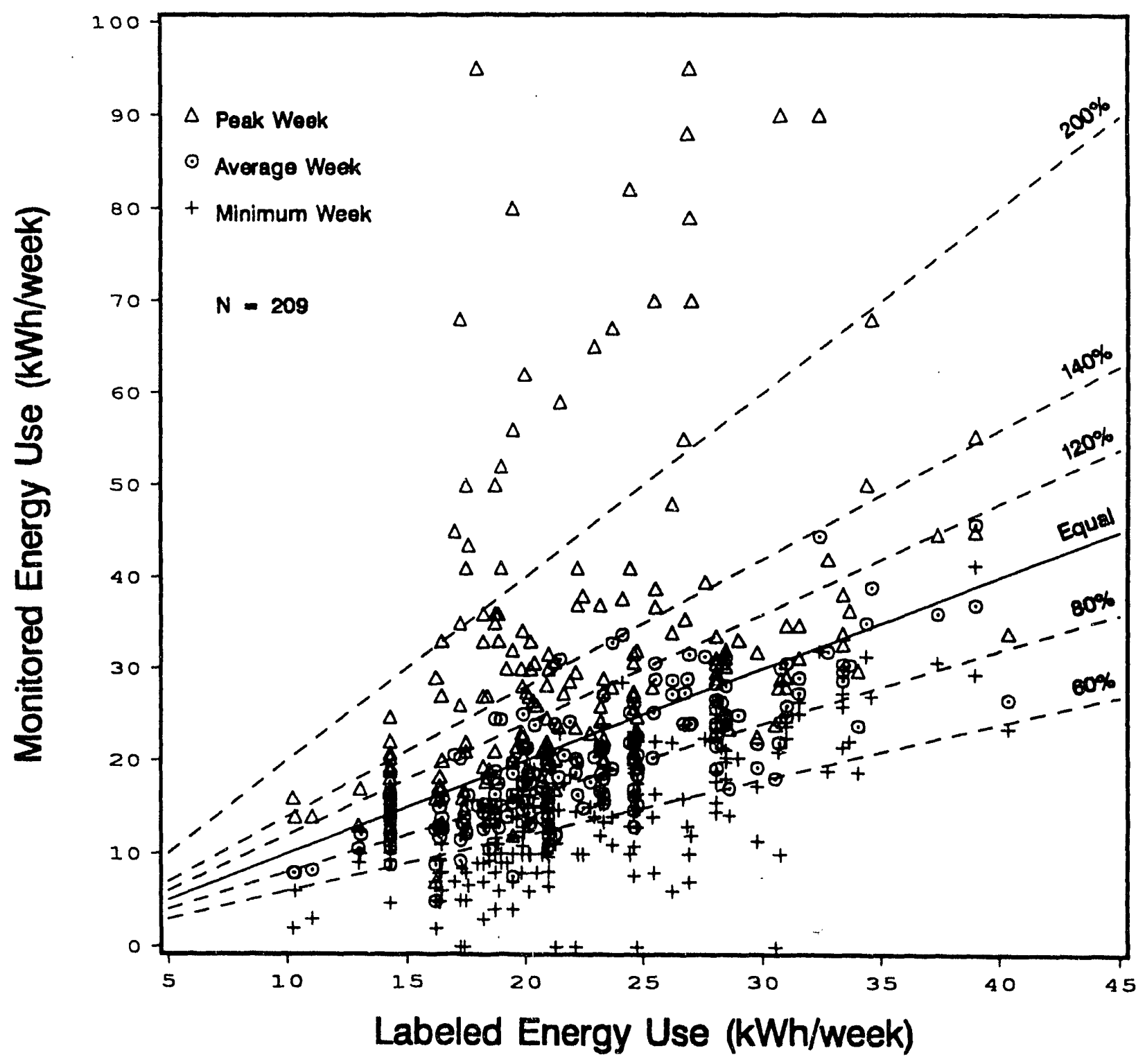

Figure 5. Peak and minimum week consumptions. Each refrigerator is represented by three symbols. For reference, the thin, solid line indicates equal consumption in label and field. The lighter dashed lines indicate where monitored energy use was $200 \%, 140 \%, 120 \%, 80 \%$, and $60 \%$ of labeled use. 

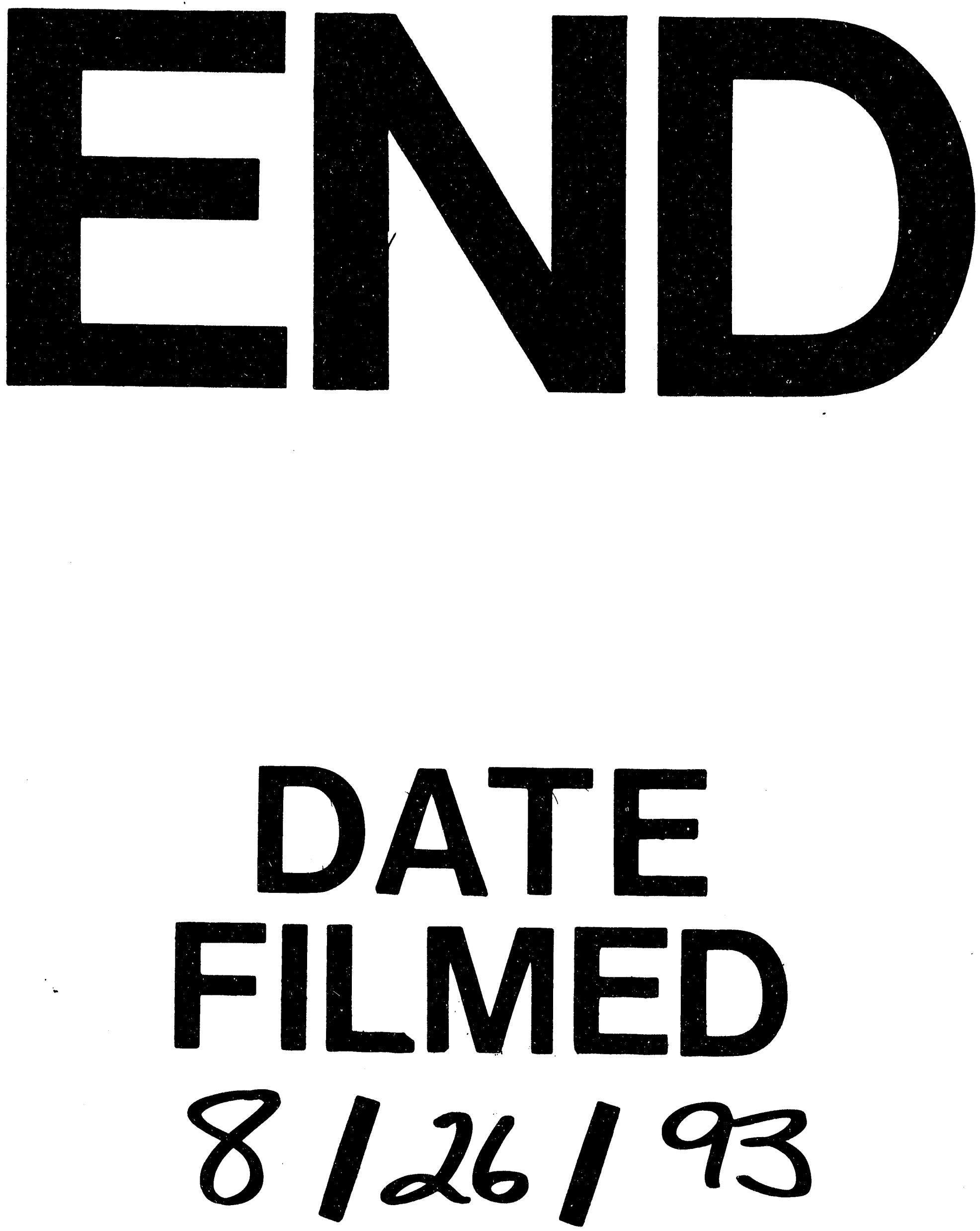
